\title{
Editorial: finding war in the present
}

\author{
William Merrin ${ }^{1} \cdot$ Andrew Hoskins $^{2}$
}

Accepted: 9 November 2020 / Published online: 10 December 2020

(c) Springer Nature Limited 2020

The Journal of Digital War has its roots in the reading, teaching, and research of the co-editors. In particular, it emerged as a response to two problems. The first was the issue of disciplinary knowledge. As editors, we are both located within the broad discipline of media and communication studies, but it is a discipline that has proved too restrictive for understanding war and conflict. Its focus was primarily on journalistic war reporting, on media coverage of wars, on the analysis and counting of content, and on audience reception. It was theoretically limited and explicitly hostile to questions of technology (having trained itself that any discussion constituted 'technological determinism'); it had little interest in new developments such as drones or cyberwar; was weak on questions of international politics and science; and was locked into a broadcast era bias that failed to recognise how much digital technology was remaking the entire ecology.

Politics, international relations, and security studies offered much that was missing, but had its own lacunae, built-in biases, and limitations, as did cultural studies and sociology. It was clear, therefore, that to understand contemporary conflict we have to move far beyond the humanities and social sciences. A knowledge of war studies and military history, systems, and operations is obviously essential, but in a digital era, it is immersion or in-depth background in computing science, cybersecurity, AI and robotics, and, indeed, in almost every area of science, that is important.

Then, there is an entire spectrum of practitioners and commentators, including science journalists and technology commentators, military actors and specialists, diplomats and politicians, and scientists, cybersecurity experts, and researchers at policy organisations, think tanks, and government centres. Add to this all the other disciplines and areas of expertise, insight and practical knowledge so far

\footnotetext{
Andrew Hoskins

andrew.hoskins@glasgow.ac.uk

Swansea University, Swansea, UK

2 University of Glasgow, Glasgow, UK
}

left out-geography, memory studies, domestic and international law, information studies and archivists, artists, photographers, historians and more-who are also vital to the conversation around contemporary war and conflict, and the limits of a great deal of disciplinary-bound work become even more apparent.

There is certainly an academic discourse that promotes the value of interdisciplinarity. But, in reality, its practice is extremely challenging. There are many barriers-across campuses and between research cultures, traditions, methods, concepts, theories, funding and publishing routeswhich make it difficult to achieve. We believe that contemporary war and conflict cannot be fully illuminated without this interdisciplinarity. Thus, the ambition of this journal is to find a way to bring together different researchers, from around the globe, into a conversation with each other, to share the insights and understanding they have to offer. This will be an ongoing project, realisable only over time.

The second issue is the tendency to think of war in specific parts. Hence, as suggested, we found media and communication studies more interested in war reporting but less in 'cyberwar' or drone technology: how one set of digital technologies, data systems, or information was used and separated off from others. This made sense if 'media studies' was simply the study of media, but once everything became digital, these boundaries didn't work. Merrin's (2018) book Digital War was a response to this. The concept was intended not as a description of a type of war (like 'information war' or 'network-centric warfare'), or an era of warfare (like 'postmodern war'), but instead as an open concept describing a new and emerging research field. To understand how wars and conflicts happen today-across much of the world-we have to understand military technologies and systems, drones, computer network exploitation and ISR, AI and robotics, augmentation technologies, espionage, propaganda, traditional media coverage, images and video, social media, etc., and we have to understand all of these simultaneously. They all feed into each other and occur in tandem, with developments in one area impacting upon or being fed by developments in another. 
This was a call for a more holistic vision of war, using the concept of 'digital war' not as a rigid, prescriptive framework, but as an expansive vision, as an invitation to put all these aspects of war into conversation with each other and track their interrelationships. Digital technologies are referenced here not to serve as a deterministic force, or as the privileged core of warfare today, but rather as a means to initiate conversations between contemporary modes, expressions, and experiences of warfare today. And just as these technologies have brought anyone and everyone into war, so all these different uses and applications and actors all need to be understood together. If we are to understand what warfare is in the twenty-first century, how it operates, its effects and where it is going, we need to consider all these elements as a whole. Merrin's Digital War made an attempt at this, in bringing together a range of disciplinary studies and aspects of contemporary war within one text, but no field can ever be summarised by one author.

Ford and Hoskins in their forthcoming Radical War: Data, Attention and Control in the Twenty-First Century also tackle some of the profound challenges of siloed disciplines and their almighty hangover of twentieth-century concepts, theories and methods, clouding a vision of twenty-firstcentury warfare. They argue that 'radical war' expands the parameters and participants of war into everyday and everywhere realms, obscuring the contexts, causes, and effects of war through processes of datafication so as to radically alter our fields of perception. Multimedia smartphones, messaging apps, and social media platforms have disrupted the relationship between warfare and society, creating a global, participative arena, in which the distinctions of combatant, civilian, and informational warrior implode. Thus, Ford \& Hoskins contend that war in the digital age thrives precisely because the fundamental relationship between perception, knowledge, and action has changed.

Just from our own work, it was obvious that there is plenty of scope for an ambitious and indeed adventurous journal that opened up, rather than closing down, the field. It was clear to us that there is great potential to establish a new field and remake our understanding of war and conflict. The Journal of Digital War is the result.

In this inaugural issue, we are delighted to include contributions from: Art, Sociology, Media, Culture \& Communication, Multi-Media Art, Law, Visual Culture, Art and Activism, International Relations, Conflict History \& Archaeology, Memory Studies, International Security, Journalism, Design, Open Source Investigations, Human Rights, War Studies, Cybersecurity, Political Science, War Gaming, and Cultural \& Political Geography. We are very grateful to our contributors for their important invited interventions.

As Merrin explains $(2018,2)$, when he began teaching this subject over a decade ago, it was more of a specialist niche, only making news when major events happened, such as terror attacks, western reprisals, or new, western conflicts. Over the years, its subject matter gained in popular awareness, new, popular and academic texts began to appear, developments in weapons systems such as drones and robots began to be publicly debated, and the growing impact of digital technologies and social media began to be understood. Topics such as hacking, hacktivism, digital civil wars, and government surveillance came to the fore; the success of Islamic State meant everyone was discussing online terrorism and propaganda; wars across the world played out now on social media platforms and people's smartphones with new kind of participation in war; and new developments in military A.I., simulation, augmentation, and weaponry made the news. Soon, everyone became conversant with the subject of cyberwar and nation state and hacking group cyberattacks, and discussions of 4Chan, trolling, the weaponisation of Facebook, Twitter bots, Troll Farms, and Russian information war became common. By the time the book Digital War was completed, digital war had gone mainstream. If WWIII is happening today, then there's no better time for The Journal of Digital War.

In our essay 'Tweet Fast and Kill Things' (Merrin and Hoskins 2020) in this volume, we cite McLuhan, who saw all of this coming: after WWI's railway war, World War II's radio war, and Vietnam's TV war, he suggested, 'World War III is a guerrilla information war with no division between military and civilian participation' (McLuhan 1970, 66). Like much of his work on the 'wired', global village, Marshall McLuhan's remark has come to resonate fifty years later, helping illuminate where we've arrived. McLuhan himself, however, was (and, indeed, remains) unpopular with many academics, for his eschewal of their conventions. Invited to speak at Columbia University in 1955 as a relatively unknown professor, he delivered a typically idiosyncratic paper to a roomful of luminaries that included the then most famous sociologist, Robert Merton. When he'd finished, Merton began the questioning, expecting to begin an academic debate about the demerits of the paper. McLuhan was uninterested, paraphrasing Groucho Marx in his reply: 'You don't like those ideas. I got others!' (Marchand 1998, 142). It was glib, rude, and dismissive, it was already typical McLuhan, but it was also much more than that, in seeding a new, more radical approach. McLuhan would later describe his ideas as 'probes', comparing himself to a safecracker, listening for the combination to click. If one idea didn't work — didn't unlock the problem — then he'd happily ditch it to find one that would (McLuhan and Zingrone 1995, 236). The world is moving fast: there isn't time to bother with ideas that don't do anything. Move on, try another.

He explained this in other ways too, such as his concept of 'pattern recognition'. He liked the story of Poe's drowning mariner who learnt to read the currents of the whirlpool to save himself. In the photo-book The Medium 
is the Massage, he says this kind of understanding 'offers a possible stratagem for understanding our predicament, our electrically-configured whirl', a claim presciently illustrated on the adjoining page in the book with a photograph of McLuhan himself (?) holding his hat and surfing the waves (McLuhan and Fiore 1996, 150-151). This was what you did: you found the pattern that enabled you to surf the maelstrom.

McLuhan, therefore, ignored conventional methodologies, implicitly rejecting more empirical approaches as he argued we didn't even necessarily see the world: 'we look at the present through a rear-view mirror', he said, like travellers in a car, hurtling forward but seeing only what's behind us, interpreting the present only in terms of the already known, the already familiar, and the past (McLuhan and Fiore 1996, 75). As Eric McLuhan comments, Marshall had no interest in predicting the future-that was an easy game, anyone could do it-he was more interested in trying to 'predict' the present (Benedetti and Dehart 1997, 186).

Probes, pattern recognition, predicting the present: these ideas-that the present is what we need to work the hardest to grasp; that we miss it if we're too locked into assumptions, ideas, concepts, and knowledge too rooted in the past; that it takes work to discover it, to put all its elements together and accurately read it; and ultimately that the flash of insight is worth more than the predictable and pointless, worthy performance of accepted methodologies (that mostly tell us what we knew all along or could just have guessed)—remain a central inspiration for this journal.

McLuhan had little time for fitting into what other academics expected, as seen in his definition of a sociologist (or, we might suggest, of academics in general) as someone who 'permits himself to see only what is acceptable to his colleagues' (McLuhan and Carson 2003, 370-371). For McLuhan, the push through to understanding necessitated going beyond what was already known and what was conventionally accepted and acceptable, using ideas to unlock what was happening and see a present that is always further on than we think.

The Journal of Digital War embraces this spirit. It believes in the necessity of interdisciplinary research that treats contemporary war and conflict holistically, bringing together all its elements to understand its local and global effects and ripples. It believes in pushing our understanding and interpretations to discover the present of warfare. It encourages and invites original research across a range of expertise from those who want to comprehend the present and also make it comprehensible across academic, cultural, and regional boundaries. It encourages radical visions, arguments, debates, and ideas that are unacceptable to disciplinary colleagues, and we call for proposals to this end for publication of agenda setting interventions, interviews, artworks, symposia, and reviews, as well as full research articles: https://www.palgrave.com/gp/journ al/42984/authors/aims-scope.

Through these contributions and conversations, the journal aims to be a leading voice, establishing a new, interdisciplinary field and contributing to an understanding of war and conflict for anyone today with an interest or concern. Given how important the subject is, and, taken together, the potential consequences of every element of digital war, this is a space and forum that is urgently needed.

If, as cultural theorist Paul Virilio once said (channelling McLuhan), 'We are always one war behind' (Virilio 2002, 35), then WWIII may be the least of our problems. Russian disinformation and 'troll-farms' are so 2016. Perhaps, it's today's WWIV we should be thinking about.

William Merrin and Andrew Hoskins

Co-Editors

The Journal of Digital War

\section{References}

Benedetti, Paul, and Nancy DeHart (eds.). 1997. Forward Through the Rear-View Mirror: Reflections on and by Marshall McLuhan. Cambridge: MIT Press.

Ford, Matthew and Hoskins, Andrew. 2021. Radical War: Data, Attention \& Control in the Twenty-First Century. (Forthcoming).

Marchand, Philip, M. 1998. Marshall McLuhan. The Medium and the Messenger. Cambridge: MIT Press.

McLuhan, Eric, and Frank Zingrone (eds.). 1995. Essential McLuhan. London: Routledge.

McLuhan, Marshall. 1970. Culture is Our Business. New York: McGraw Hill.

McLuhan, Marshall, and David Carson. 2003. The Book of Probes. Corte Madera, CA: Gingko Press.

McLuhan, Marshall, and Quentin Fiore. 1996. The Medium is the Massage. San Francisco: HardWired.

Merrin, William. 2018. Digital War. Abingdon, Oxon: Routledge.

Merrin, William, and Andrew Hoskins. 2020. Tweet Fast and Kill Things: Digital War. Digital War. https://doi.org/10.1057/s4298 4-020-00002-1.

Virilio, Paul. 2002. Ground Zero. (Translated by Chris Turner). London: Verso.

William Merrin is an Associate Professor of Media Studies at Swansea University, UK. He is the author of Digital War (Polity, 2018), Media Studies 2.0 (Routledge, 2014), and Baudrillard and the Media (Polity, 2005), and the co-editor of Trump's Media War (2019) and Jean Baudrillard: Fatal Theories (Routledge, 2009). He is the Founding Co-Editor-in-Chief of the Journal of Digital War.

Andrew Hoskins is an Interdisciplinary Research Professor in the College of Social Sciences at the University of Glasgow, UK. His books include: Trump's Media War (Palgrave 2019, Co-Ed); Digital Memory Studies: Media Pasts in Transition (Routledge 2018, Ed.); and Risk and Hyperconnectivity: Media and Memories of Neoliberalism (OUP 
2016, with John Tulloch). His latest book (with Matthew Ford) Radical War: data, attention and control in the twenty-first century will be published in 2021. He is the founding Co-Editor-in-Chief of the Journal of Digital War, founding Editor-in-Chief of the Journal of Memory
Studies, founding Co-Editor-in-Chief of the Journal of Memory, Mind $\&$ Media, and founding Co-Editor of the Routledge book series Media, War, and Security. 